\title{
Bioengineering in a Poultry Facility in Northern Colombia
}

\author{
Carlos Millán-Páramoํㅜㄹ Euriel Millán-Romero ${ }^{2}$ and Fernando Jove Wilches ${ }^{1}$ \\ ${ }^{1}$ Department of Civil Engineering, Universidad de Sucre, Sincelejo, Sucre, Colombia. \\ ${ }^{2}$ Faculty of Engineering, Universidad de Sucre, Sincelejo, Colombia.
}

ORCIDs: 0000-0002-0004-6063 (Carlos), 0000-0001-7955-9963 (Euriel), 0000-0002-2080-4036 (Fernando)

\begin{abstract}
The renewal of air inside the shed is a factor that must be controlled, considering that the birds are responsible for producing the greatest amount of heat. An excessive increase in temperature and humidity can be controlled by removing the hot air and replacing it with fresh air from outside. Chickens for fattening are more vulnerable to high temperatures especially the last two weeks of life. The objective of this work is to determine the natural and forced ventilation for an open installation of chickens for fattening under confinement, built with conventional materials. The study is carried out at the El Perico farm, belonging to the University of Sucre, Department of Sucre-Colombia. Ventilation for hot weather is determined with the support of the psychrometric chart; considering the heat of the animals, heat transmission by the materials of the construction parts of the shed, based on the internal and external conditions of temperature and relative humidity. The total ventilation required in the installation is $43522.66 \mathrm{~m} 3 / \mathrm{h}$, indicating that there is no problem with air supply since the area to ventilate is much less than that provided by the shed. There is an inconvenience due to the thermal sensation of the animals and humidity, so it is necessary to supply fans (mechanical ventilation) for the chickens, in a quantity of three (3). Each fan has a flow of $16000 \mathrm{~m} 3 / \mathrm{h}$ and a power of $1.0 \mathrm{HP}$.
\end{abstract}

Keywords: Ventilation flow, heat transfer, chickens for fattening, building materials, environmental conditions.

\section{INTRODUCTION}

In general, the environment is the sum of all external conditions and circumstances that affect an animal's health, well-being, productivity and reproductive efficiency. Includes all factors around animals that affect them, such as management, nutrition, social aspects and diseases. In addition, it includes climatic factors such as temperature, humidity and ventilation, which must be managed appropriately or modified, if practical, to obtain good production efficiency. The environment affects the degree of expression of the genetic potential of an animal [1].

The environment can be divided into three factors as follows: (i) physical, (ii) social and (iii) thermal [1]. Physical factors refer to aspects such as space, light, sound, pressure and facilities in general. Social factors are group size, dominance orders, and other aspects of animal behavior. Thermal factors refer to air temperatures, relative humidity, air currents, radiation, among others. Animals cannot be separated from their environment, nor can their production be considered in isolation from that environment. Periodic evaluation of the environment is necessary to determine if the system is making the best use of the available resources, in an ecologically friendly way, while meeting the needs of the rural family and society in general.

An environmental control is essential for a good performance of the productive process of the poultry facility, in most cases poor ventilation or poor control of environmental conditions and temperature are the cause of poor performance, and not the causes which are adduced as the type of animal or feed. As for the temperature, you have to be very demanding with the installation of ventilation, since there are optimal temperatures at every moment of the aging process, starting at $33^{\circ} \mathrm{C}$ and decreasing over the weeks until reaching $21^{\circ} \mathrm{C}$. Due to the high temperature requirements at the beginning of the fattening process, the house can be subdivided, establishing fences, to avoid having to heat the entire house, and only heat certain areas of it [2].

For many years, producers and scientists have worked to develop management systems that maximize daily weight gain, feed utilization, milk production, eggs per hen, and other productivity parameters. However, in recent years, with increases in costs in general (energy, etc.), the interest has changed from the goal of: "Maximum Production Levels" to "Cheaper Production Levels". The calculations of the CostBenefit relationship allow us to appreciate the relative profitability of the provision of shade, thermal insulation, supplementary heat, fans, sprinklers and other measures aimed at modifying the environment, according to species and production systems [3].

Animals respond to physical, social, climatic stimuli, etc., from their surroundings. This external environment, which represents all the non-genetic factors that influence the response, interacts with the animal's genotype to determine its performance. In animal production systems this situation is even more complex, since human intervention can influence both the genotype and the external environment. Under these conditions, productivity depends on a genotype-environmentmanagement interaction. All species respond to changes in their natural environment by altering their physiology and phenotype Wild animals experience continually changing conditions, so their survival often depends on their ability to adjust or adapt to new circumstances. In this context, if a species finds that its existence in a certain region is threatened by lack of food, inclement weather, excess predators or other causes, it can, if it 
has mobility, simply move to a more favorable area and survive without genotypic or phenotypic changes [4].

Homeothermic animals (warm blooded and endothermic), which comprise all farm mammals and birds, maintain a relatively constant body temperature using or dissipating energy. If internal or deep body temperatures change moderately from normal temperature, they die in a relatively short time. Among farm animals, normal rectal temperature ranges from $38^{\circ} \mathrm{C}$ for horses to $41.1^{\circ} \mathrm{C}$ for birds. Body temperature experiences a small daily (daytime) variation of a few degrees, usually decreasing in the early morning and increasing towards dusk [3]. Homeothermic animals to keep their body temperature constant, the heat produced plus the heat eventually gained from the outside (for example, by direct solar radiation), must equal the lost heat. Heat exchanges are regulated in such a way that, in a given period of time, the heat produced inside the body is equal to the amount of heat lost (thermal equilibrium), thus allowing the maintenance of a constant body temperature [5].

Convection is the flow or transfer of heat through the movement of air or water. It is due to the redistribution of molecules within the fluid in question (air, water). In animals, convective heat transfer occurs between the external surface of the body and the surrounding air. Under windy conditions the heat is removed by forced convection to an extent that depends on the speed and direction of the wind. In still or calm air conditions, the movement of the air around the animal body is a consequence of the natural upward movement of the air (the warm air rises) and the heat is removed, minimally, by free convection. Equivalent processes for confinement buildings are wind ventilation and the chimney effect. Heat loss to the external environment is done through two main routes or ways. Firstly, by the non-evaporative transfer of heat to the air and adjacent surfaces of the animal through radiation, convection and conduction. Second, through the transfer of evaporative heat, associated with the loss of water vapor from the body surface and the respiratory system [6]. On the other hand, this increase in heat losses by convection, as a consequence of air currents, is one of the effective means of fighting against very high temperatures [7]. Conduction is the flow or transfer of heat between an animal and any surface, particularly the floor, with which it is in contact. Unlike convection, there is no relative translocation of molecules. Hotter molecules impart kinetic energy to cooler molecules through direct contact. Radiation is the exchange of heat between two objects that are not in contact. Heat flows from the hottest object to the coldest. For example, a calf standing in the sun on a clear winter day receives solar heat through radiation. Radiant energy moves in space through electromagnetic waves that propagate in a straight line. It is transformed into thermal energy upon contact with the animal.

There are other components of the environment, such as relative humidity, light, sounds and the direct effect of radiation. This could also include harmful gases or environmental pollutants that are produced in the housings of the systems under confinement. The objective of this work was to determine the natural and forced ventilation for a chicken for fattening poultry facility built with conventional materials.
The remainder of this paper is organized as follows. In Section 2 , the ventilation parameters are described. Section 3 describes the determination of ventilation. Finally, in Section 4, our conclusions are presented.

\section{VENTILATION PARAMETERS}

\section{II.I Ventilation Parameters}

The most vital need of living beings is the supply of oxygen. Therefore, the ventilation by which we provide this element to the chickens during their upbringing is necessary to a greater or lesser extent from before their birth since the embryonated eggs placed in the incubator need their contribution from the beginning of their development. Correct ventilation allows to maintain:

(i) A quality air that provides the necessary oxygen more than $20 \%$ for correct breathing.

(ii) Elimination of toxic gases such as carbon dioxide and ammonia, the levels of which must be below 3,000 ppm and 20 ppm, respectively.

(iii) An optimal temperature for maximum use of the feed, defined as the "comfort temperature".

(iv) A relative humidity -HR- of $50-70 \%$.

(v) A homogeneous distribution throughout the installation of the desired environmental conditions, without drafts, thermal differences, etc.

These five factors are related to each other, in such a way that the modification of any of them affects any of the others. In any case, if adequate ventilation is established to control the temperature and $\mathrm{RH}$ in its correct parameters, the necessary oxygen supply and the elimination of excessive toxic gases are obtained. Table 1 shows the optimal temperature and relative humidity conditions for maximum performance of the chickens. These conditions are indicative, in such a way that the careful observation of the chickens is basic and fundamental to adjust them depending on the farm, the weather, among others [8].

Table 1. Optimal temperature and relative humidity conditions

\begin{tabular}{|c|c|c|}
\hline Days old & Temperature $\left({ }^{\circ} \mathrm{C}\right)$ & Relative humidity (\%) \\
\hline 1 & $31-32$ & 50 \\
\hline 7 & $29-30$ & 52 \\
\hline 14 & $27-28$ & 55 \\
\hline 21 & $24-26$ & 60 \\
\hline 28 & $21-23$ & 65 \\
\hline 35 & $19-21$ & 67 \\
\hline 42 & $18-20$ & 70 \\
\hline
\end{tabular}

\section{II.II. Climatic factors}

The climatic conditions of the different zones determine the design and equipment of the farms. In our area of influence, where the climate is extreme, they must have effective ventilation systems since the productive results throughout the year are determined by the climatic conditions that are manifested at the time. The farms must have systems that, through proper management, compensate the unfavorable 
conditions for the comfort of the chickens. This is achieved with sufficient and controllable ventilation systems. Regarding ventilation, it must allow the control of the incoming and outgoing air flow; the air velocity at the chicken level; the air flow circuit; static pressure.

It is important to pay special attention to the air quality inside the poultry houses as part of the production under parameters of animal welfare $[9,10]$. Table 2 indicates broiler parameters such as water vapor, total heat, and $\mathrm{CO} 2$ [11]. Ventilation rates for broilers in temperate regions during winter and summer (m3/h.kg live weight) are 0.74 and 2.80-4.64 respectively [11].

Table 2. Influence of birds (chickens for fattening) on the environment of the accommodation

\begin{tabular}{|c|c|c|c|}
\hline $\begin{array}{c}\text { Live weight } \\
(\mathrm{kg})\end{array}$ & $\begin{array}{c}\text { Water vapor } \\
\mathrm{g} / \mathrm{h}\end{array}$ & $\begin{array}{c}\text { Total heat } \\
(\mathrm{kcal} / \mathrm{h})\end{array}$ & $\begin{array}{c}\mathrm{CO}_{2} \\
(\mathrm{l} / \mathrm{h})\end{array}$ \\
\hline 0.055 & 0.5 & 0.6 & 0.1 \\
\hline 0.165 & 1.0 & 1.7 & 0.3 \\
\hline 0.310 & 1.6 & 2.8 & 0.5 \\
\hline 0.520 & 2.4 & 4.1 & 0.7 \\
\hline 0.700 & 2.9 & 5.1 & 0.9 \\
\hline 1.130 & 4.0 & 7.0 & 1.1 \\
\hline 1.630 & 4.9 & 8.9 & 1.3 \\
\hline 2.200 & 5.5 & 10.2 & 1.5 \\
\hline
\end{tabular}

\section{II.III. Formulation to determine ventilation parameters}

For cold weather ventilation is calculated by equation 1, where: $\mathrm{V}=$ flow in $\mathrm{m} 3 / \mathrm{h} ; \mathrm{X}=\mathrm{g} / \mathrm{h}$ of water vapor to extract from the housing. It is the product of the water vapor emitted by each animal housed $\mathrm{x}$ the number of animals $\mathrm{x}$ coefficient of major (1.5 to 2.0); hi=Absolute humidity of the air inside the housing at the optimum temperature and relative humidity, expressed in $\mathrm{g} / \mathrm{m} 3$ and he=absolute humidity of the air outside the housing at the existing temperature and relative humidity expressed in $\mathrm{g} / \mathrm{m} 3$.

$$
\mathrm{V}=\frac{\mathrm{X}}{\mathrm{h}_{\mathrm{i}}-\mathrm{h}_{\mathrm{e}}}
$$

For warm weather, the flow to be removed is expressed in equation 2, where: $\mathrm{V}=$ flow in $\mathrm{m} 3 / \mathrm{h}$; $\mathrm{q}=$ heat produced by livestock in $\mathrm{kcal} / \mathrm{h} ; 0.3$ is the specific heat of air, in $\mathrm{kcal} / \mathrm{m} 3 .{ }^{\circ} \mathrm{C}$ and $\Delta \mathrm{t}=$ Outside and inside temperature difference, in ${ }^{\circ} \mathrm{C}$.

$$
\mathrm{V}=\frac{\mathrm{q}}{0.3 \Delta \mathrm{t}}
$$

Using the psychrometric chart, the flow is expressed in equation 3, where: $\mathrm{V}=$ flow in $\mathrm{m} 3 / \mathrm{h} ; 25 \%$ is added as a coefficient of majority (1.25); $\mathrm{P}=$ water vapor to extract in $\mathrm{g} / \mathrm{h}$.animal; $\mathrm{Pi}=$ indoor air humidity in ( $\mathrm{g}$ water vapor/m3 of air); $\mathrm{Po}=$ humidity of outdoor air in ( $\mathrm{g}$ water vapor/m3 of air) and $\mathrm{n}=\#$ of animals.

$$
\mathrm{V}=\frac{\mathrm{nP}}{\mathrm{P}_{\mathrm{i}}-\mathrm{P}_{\mathrm{o}}}
$$

Coefficient of heat transmission $(\mathrm{K})$ through the element, is expressed in equation 4 , where: $\mathrm{K}=$ total coefficient of heat transmission (conduction, convection) in $\mathrm{kcal} / \mathrm{m} 2 . \mathrm{h} .{ }^{\circ} \mathrm{C}$ and $\mathrm{R}=$ thermal resistance coefficient in h.m $2 .{ }^{\circ} \mathrm{C} / \mathrm{kcal}$.

$$
\mathrm{K}=\frac{1}{\mathrm{R}}
$$

Thermal resistance coefficient ( $R$ ) through the element, is expressed in equation 5, where: $\mathrm{R}=$ thermal resistance coefficient, in h.m $2 .{ }^{\circ} \mathrm{C} / \mathrm{kcal}$.

$$
\mathrm{R}=\frac{1}{\mathrm{X}_{\mathrm{i}}}+\frac{\mathrm{d}_{1}}{\lambda_{1}}+\frac{\mathrm{d}_{2}}{\lambda_{2}}+\cdots+\frac{1}{\mathrm{X}_{\mathrm{e}}}
$$

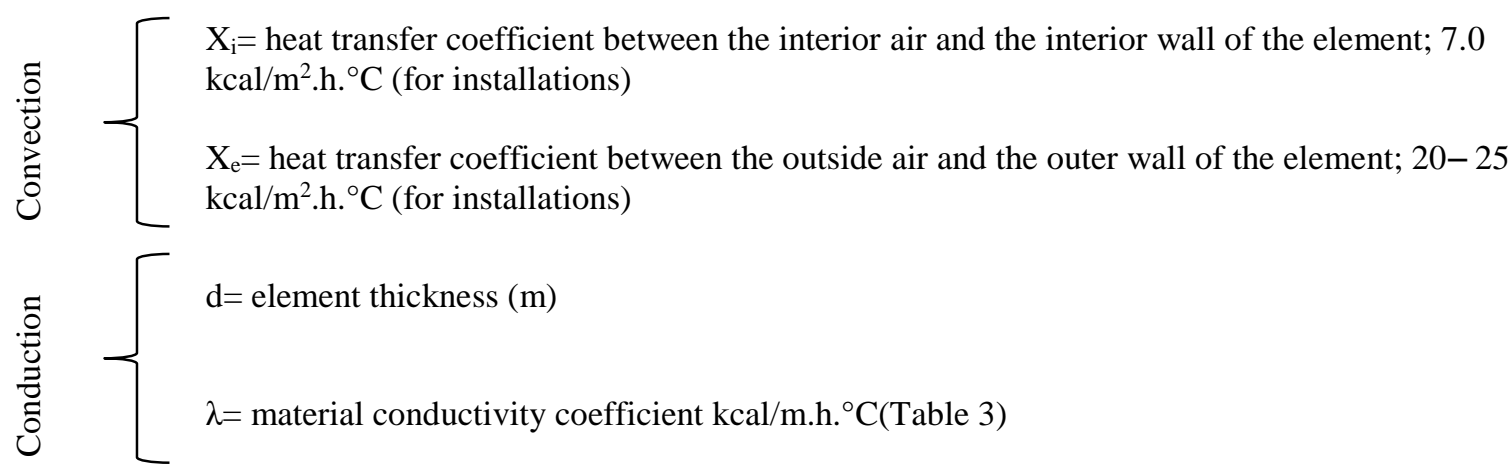

Table 3. $\lambda$ values $\left(\mathrm{kcal} / \mathrm{m} . \mathrm{h} .{ }^{\circ} \mathrm{C}\right)[11]$

\begin{tabular}{|l|l|l|l|}
\hline Material & $\lambda$ & Material & $\lambda$ \\
\hline Wet ground & 2.0 & Lime and cement mortars & 0.60 \\
\hline Wet gravel & 2.0 & Glass & 1.05 \\
\hline Dry gravel & 0.7 & zinc & 95 \\
\hline Concrete block & 0.5 & Iron and Steel & 50 \\
\hline Hollow brick & $0.35-0.40$ & Aluminum & 175 \\
\hline Solid brick & 0.90 & Woods & $0.10-0.15$ \\
\hline Concrete & 1.30 & Cork & 0.035 \\
\hline Air chamber $(3-6 \mathrm{~cm})$ & $5.0-5.5$ & Rubber & 0.20 \\
\hline
\end{tabular}


Total heat in the housing $(\mathrm{Q})$, is expressed in equation 6, where: $\mathrm{Q}=$ total heat, in $\mathrm{kcal} / \mathrm{h} ; \mathrm{K}=$ total coefficient of heat transmission (conduction, convection), in $\mathrm{kcal} / \mathrm{m} 2 . \mathrm{h} .{ }^{\circ} \mathrm{C}$; ti and te=indoor and outdoor temperature, in ${ }^{\circ} \mathrm{C}$ respectively and $\mathrm{s}=$ total area, in $\mathrm{m} 2$.

$$
\mathrm{Q}=\mathrm{K} \cdot(\mathrm{ti}-\mathrm{te}) \cdot \mathrm{s}
$$

The natural ventilation flow $(\mathrm{V})(\mathrm{m} 3 / \mathrm{h})$ of the installation is calculated based on the wind speed (v) in $\mathrm{m} / \mathrm{h}$ and the window area $(\mathrm{A})$ in $\mathrm{m} 2$, by equation 7 :

$$
\mathrm{V}=\mathrm{v} \cdot \mathrm{A}
$$

\section{DETERMINATION OF VENTILATION}

\section{III.I Study area}

The study was carried out at the El Perico farm that owns the shed for chickens for fattening (broiler, weight at 38 days 1.85 $\mathrm{kg}$ ), belonging to the Universidad de Sucre, located on the left bank of the road leading from Sincelejo to the municipal seat of Sampués, with geographic coordinates of $9^{\circ} 12^{\prime} \mathrm{N}$ and $75^{\circ} 26^{\prime}$ $\mathrm{W}$ [12]. This headquarters has an extension of 11.8 ha. It is characterized by being an area belonging to the tropical dry forest [13].

\section{III.II Temperature and relative humidity}

The temperatures (Fig. 1) and relative humidity (Fig. 2) within the shed were determined during the evaluation days (age of the chickens), measured using a thermo hygrometer. The mean temperature was $28^{\circ} \mathrm{C}$ and the relative humidity was $80 \%$. The external temperature to the shed was $31^{\circ} \mathrm{C}$ and the relative humidity $70 \%$. The air speed of $1.38 \mathrm{~m} / \mathrm{s}$ (anemometer was used).

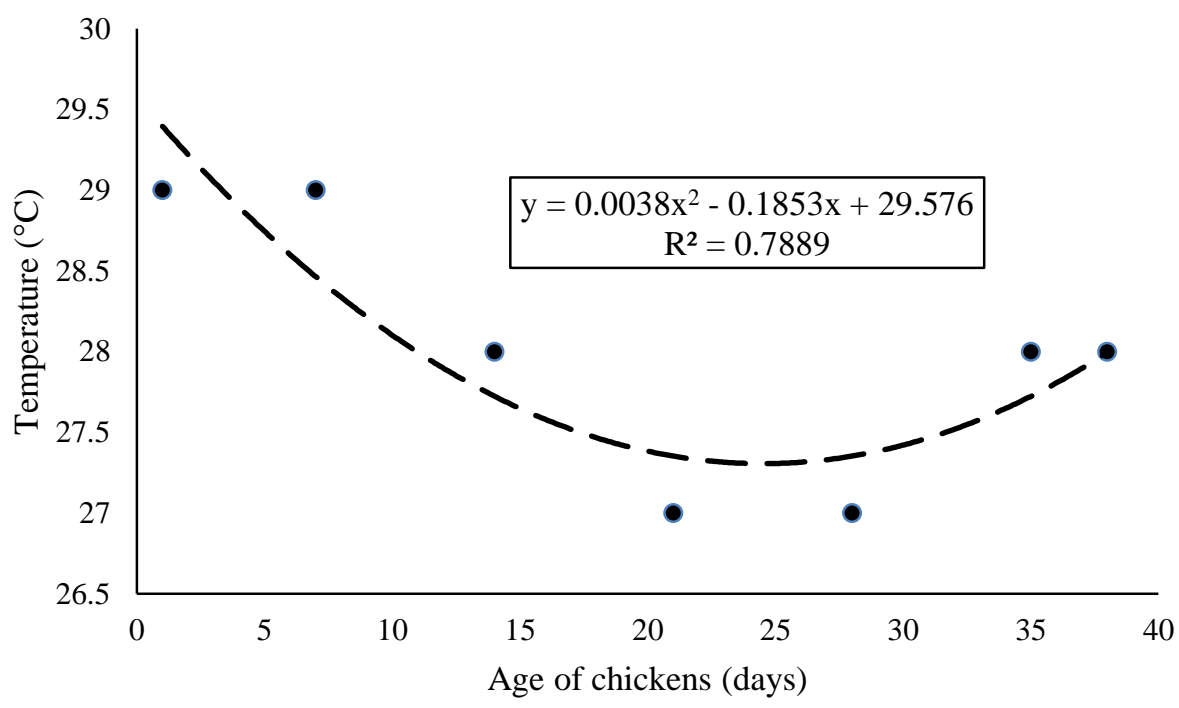

Fig. 1. Environmental temperature inside the shed during the days (age of the chickens) of evaluation

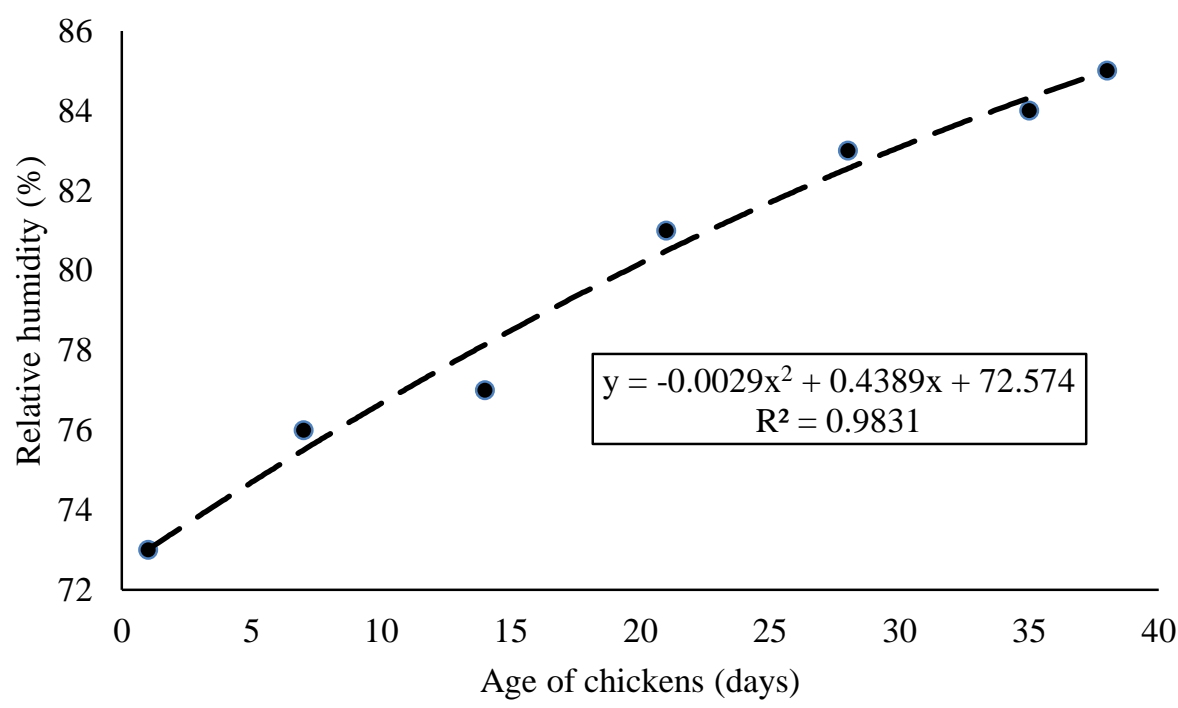

Fig. 2. Relative humidity inside the house during the days (age of the chickens) of evaluation 
International Journal of Engineering Research and Technology. ISSN 0974-3154, Volume 13, Number 11 (2020), pp. $4004-4010$

(C) International Research Publication House. https://dx.doi.org/10.37624/IJERT/13.11.2020.4004-4010

\section{III.III. Case study}

Calculate the natural and mechanical ventilation for an open house of 3,500 chickens for fattening as illustrated in Fig. 3, with an average weight of $1.5 \mathrm{~kg} / \mathrm{animal}$. Environmental conditions farm El Perico-University of Sucre are:

Internal $\rightarrow \mathrm{T}=28^{\circ} \mathrm{C} ; \mathrm{RH}=80 \%$; External $\rightarrow \mathrm{T}=31^{\circ} \mathrm{C}, \mathrm{RH}=70 \%$
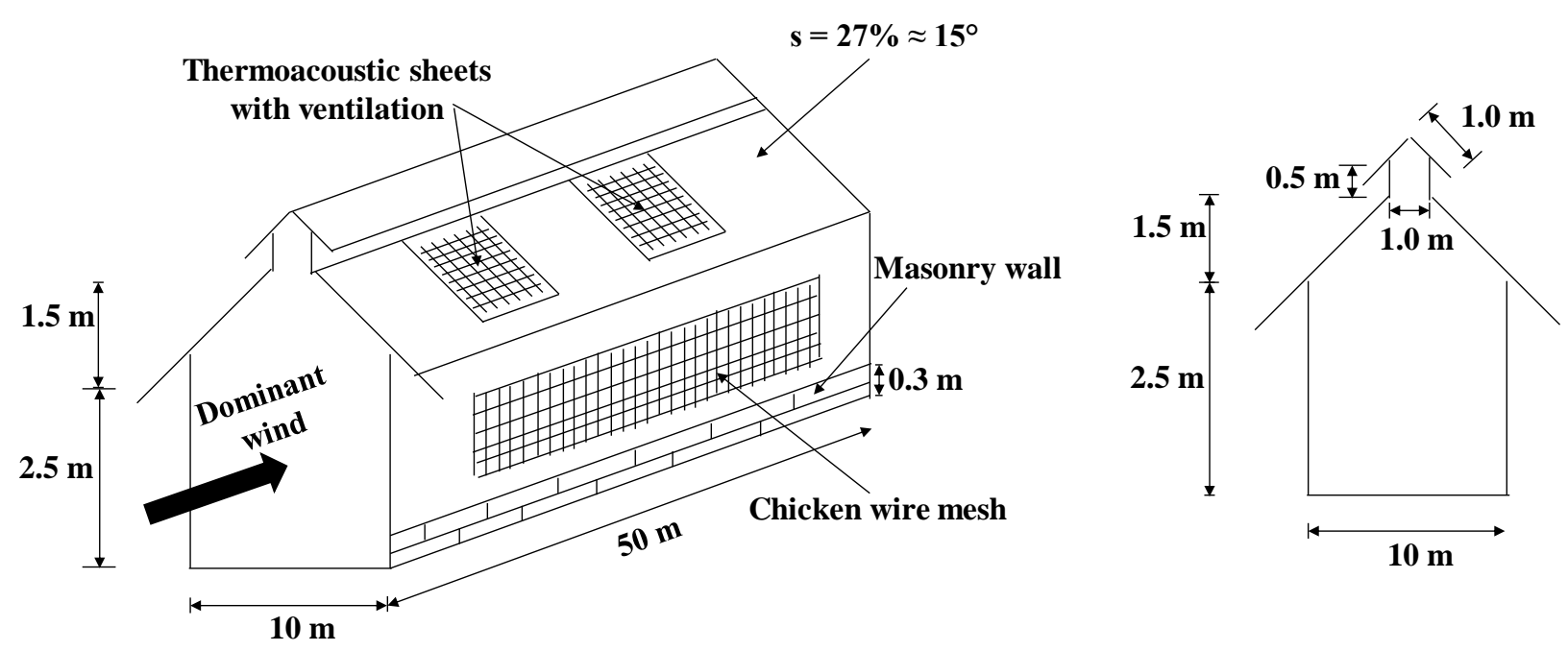

Fig. 3. Construction details of the installation

From Table 2, the total heat (Q) per animal is determined; interpolating is $8.4 \mathrm{kcal} / \mathrm{h}$.anim. Therefore, $\mathrm{V}$ is:

$$
\mathrm{V}=\frac{\mathrm{Q}}{0.3 \Delta \mathrm{t}}=\frac{(8.4 \mathrm{kcal} / \mathrm{h} \cdot \mathrm{anim}) \times 3500 \mathrm{anim}}{\left(0.3 \mathrm{kcal} / \mathrm{m}^{3} .{ }^{\circ} \mathrm{C}\right) \times 3^{\circ} \mathrm{C}}=32666.7 \mathrm{~m}^{3} / \mathrm{h}
$$

Comparing the ventilation of $32666.7 \mathrm{~m}^{3} / \mathrm{h}$ with the ventilation rates for broilers during the summer $\left(\mathrm{m}^{3} / \mathrm{h} . \mathrm{kg}\right.$ live weight) for a value of $4.0 \mathrm{~m}^{3} / \mathrm{h} . \mathrm{kg}$ live weight, we have:

$$
\begin{gathered}
\mathrm{V}=\text { Ventilation rate } \cdot \text { Coefficient of Majority } \cdot \text { animal number } \\
\mathrm{V}=4 \mathrm{~m}^{3} / \mathrm{h} . \mathrm{kg}-\mathrm{lw} \cdot 1.5 \cdot 1.5 \cdot 3500=31500 \mathrm{~m}^{3} / \mathrm{h} \\
32666.7 \mathrm{~m}^{3} / \mathrm{h}>31500 \mathrm{~m}^{3} / \mathrm{h}
\end{gathered}
$$

Comparing the two (2) ventilation calculations, the highest value is selected $\left(32666.7 \mathrm{~m}^{3} / \mathrm{h}\right)$.

Enthalpies and specific volumes are calculated with the same environmental conditions and using the psychrometric chart (Fig. 4): hi=18.4 kcal $/ \mathrm{kgDA}$; he $=19.7 \mathrm{kcal} / \mathrm{kgDA} ; \mathrm{Vi}=0.88$ $\mathrm{m}^{3} / \mathrm{kgDA}$ and $\mathrm{Ve}=0.89 \mathrm{~m}^{3} / \mathrm{kgDA}$.

$$
\Delta \mathrm{h}=\mathrm{he}-\mathrm{hi}=19.7-18.4=1.3 \mathrm{kcal} / \mathrm{kgDA}
$$

Ventilation calculation (V) for animals

$$
\mathrm{V}=\frac{(8.4 \mathrm{kcal} / \mathrm{h} . \mathrm{anim})}{1.3 \frac{\mathrm{kcal}}{\mathrm{kgAS}}} \times 0.89 \mathrm{~m}^{3} / \mathrm{kgAS} \times 3500 \text { animals }
$$

If the calculation is oriented to determine the volume of air necessary so that the $\mathrm{CO}_{2}$ concentration does not exceed 3.0 per thousand, from Table 2, the $\mathrm{CO}_{2}$ per animal is determined; interpolating is equal to $1.2 \mathrm{l} / \mathrm{h}$. anim $=0.0012 \mathrm{~m}^{3} / \mathrm{h}$. In addition, clean air contains 0.3 per thousand of $\mathrm{CO}^{2}$ concentration.

$$
\begin{gathered}
\mathrm{CO}_{2} \text { total }=3.0+0.3=3.3 \text { ppt } \mathrm{CO}_{2} \\
\mathrm{~V}-\mathrm{CO}_{2} \text { per animal }=\left(0.0012 \frac{\mathrm{m}^{3}}{\mathrm{~h}}\right) / 0.0033=0.3636 \frac{\mathrm{m}^{3}}{\mathrm{~h} . \text { animal }} \\
\mathrm{V}-\mathrm{CO}_{2}=0.3636 \frac{\mathrm{m}^{3}}{\mathrm{~h} . \text { animal }} \times 3500 \text { animals }=1272.6 \frac{\mathrm{m}^{3}}{\mathrm{~h}}
\end{gathered}
$$

This volume $\left(1272.6 \mathrm{~m}^{3} / \mathrm{h}\right)$ is less than that calculated for the environmental conditions $\left(20125 \mathrm{~m}^{3} / \mathrm{h}\right)$ in the installation, indicating that there is no problem to extract the $\mathrm{CO}_{2}$.

Finally, the heat generated by the different parts and materials of the installation is calculated, as follow:

With the parameters of Table 2 the heat of the wall is obtained.

$$
\begin{gathered}
\mathrm{R}=\frac{1}{7}+\frac{0.02}{0.60}+\frac{0.10}{0.50}+\frac{0.02}{0.60}+\frac{1}{25}=0.45 \mathrm{~h} . \mathrm{m}^{2} \cdot{ }^{\circ} \mathrm{C} / \mathrm{kcal} \\
\mathrm{K}=\frac{1}{\mathrm{R}}=2.22 \mathrm{kcal} / \mathrm{h} \cdot \mathrm{m}^{2} \cdot{ }^{\circ} \mathrm{C} \\
Q_{w}=\mathrm{K} \cdot(\mathrm{ti}-\mathrm{te}) \cdot \mathrm{s}=2.22 \cdot(31-28) \cdot 32.5 \\
=216.45 \mathrm{kcal} / \mathrm{h}
\end{gathered}
$$

Since there are two walls, this value is multiplied by 2 . Then, $\mathrm{Qw}=432.9 \mathrm{kcal} / \mathrm{h}$.

Cover heat and with $\mathrm{K}=0.5$ for a thermoacoustic sheet

$$
\begin{gathered}
\mathrm{Q}_{\mathrm{c}}=\mathrm{K} \cdot(\mathrm{ti}-\mathrm{te}) \cdot \mathrm{s}=0.50 \cdot(31-28) \cdot 750 \\
=1125 \mathrm{kcal} / \mathrm{h}
\end{gathered}
$$

The heat per floor:

$\mathrm{Q}_{\mathrm{f}}=\mathrm{K} \cdot(\mathrm{ti}-\mathrm{te}) \cdot \mathrm{s}=13 \cdot(31-28) \cdot 500=19500 \mathrm{kcal} / \mathrm{h}$ 


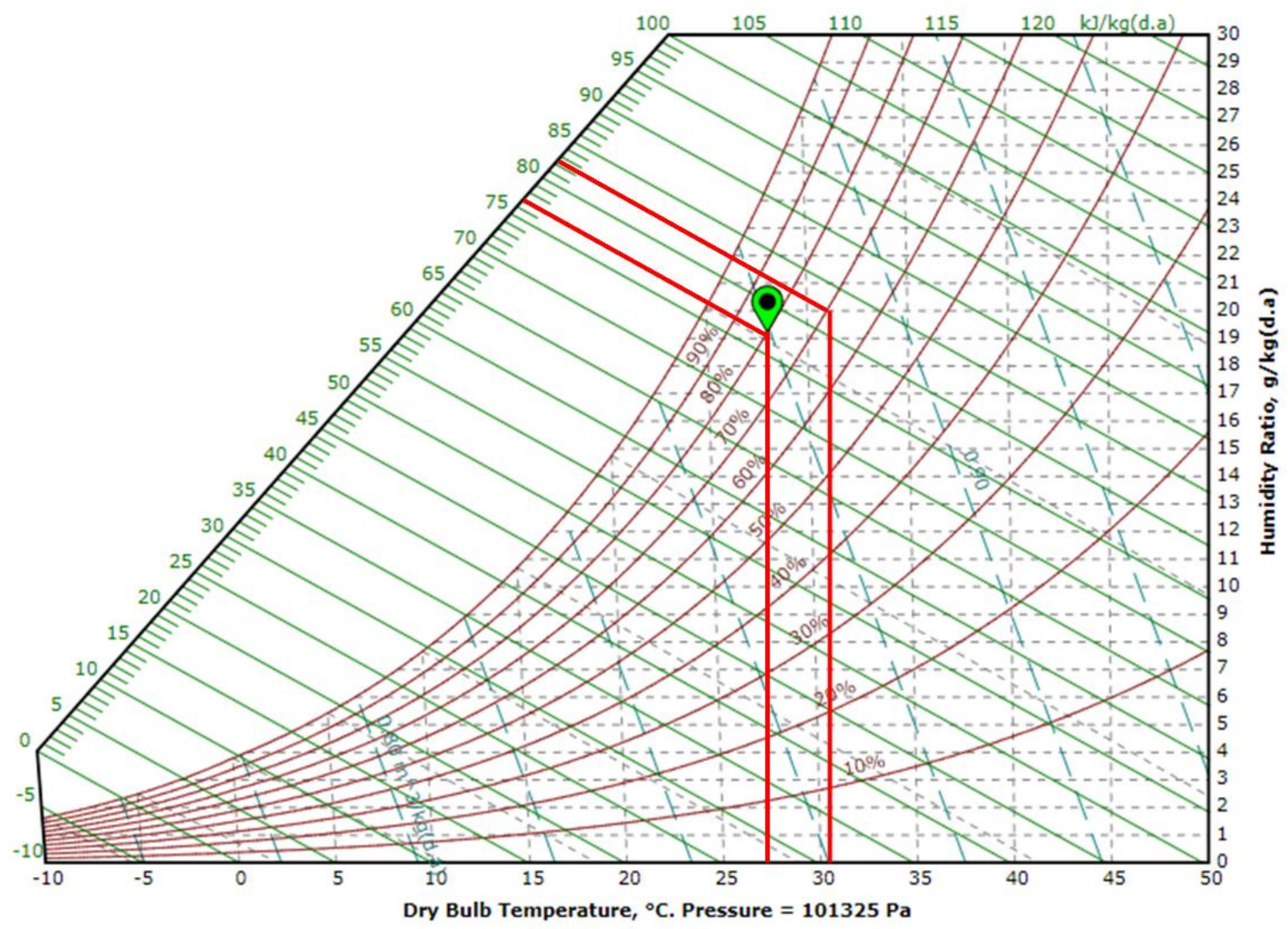

Fig. 4. Psychrometric chart

Finally, the total heat is obtained

$$
\begin{gathered}
\mathrm{Q}_{\mathrm{t}}=432.9+1125+19500=21057.9 \mathrm{kcal} / \mathrm{h} \\
\mathrm{V}=\frac{\mathrm{Q}}{0.3 \Delta \mathrm{t}}=\frac{21057.9}{0.3 \times 3}=23397.66 \mathrm{~m}^{3} / \mathrm{h} \\
\sum \mathrm{V}=20125+23397.66=43522.66 \mathrm{~m}^{3} / \mathrm{h}
\end{gathered}
$$

The ventilation for environmental conditions by the animals is equivalent to approximately $86 \%$ of the ventilation for the building's construction materials, that is, $20125 / 23397.66=86 \%$. With the total ventilation of $43522.66 \mathrm{~m}^{3} / \mathrm{h}$ and taking into account a coefficient of greater than 1.5 , air speed $(1.38 \mathrm{~m} / \mathrm{s})$, the free area of the shed is determined:

$$
\mathrm{V}=\mathrm{v} \cdot 1.5 \cdot \mathrm{A}
$$

The area (A) is smaller than the one arranged by the shed, which indicates that there is no problem for air disposal; There is a problem due to the thermal sensation of the animals and humidity (especially the last two weeks of life), so it is necessary to supply fans (mechanical ventilation) for the chickens. In well-designed tunnel-ventilated sheds with an air duct and perforations for exit to animals, the effects of humidity are minimized, especially when compared to natural ventilation systems.

With a flow rate per fan of $16000 \mathrm{~m}^{3} / \mathrm{h}$ with power $1.0 \mathrm{HP}$ :

$$
\text { \#Fans }=\frac{43522.66 \mathrm{~m}^{3} / \mathrm{h}}{16000 \mathrm{~m}^{3} / \mathrm{h}}=2.72 \approx 3.0
$$

Extensive research has been done on intrusion detection system

Averaged one dependence estimators (AODE) can provide good accuracy when performing binary classification. In addition, their training and testing times has been found to be relatively fast compared to other popular algorithms [7].

\section{CONCLUSIONS}

The use of fans is the most efficient and practical way to reduce temperature and relative humidity under tropical conditions inside chickens for fattening sheds. Most sheds in Colombia are open and the mechanical ventilation system with fans is a good option with low cost compared to the other systems.

The total ventilation required in the installation that was determined is $43522.66 \mathrm{~m} 3 / \mathrm{h}$; the area to ventilate was quite smaller than the one arranged by the shed, which indicated that there is no problem with the availability of air or $\mathrm{CO} 2$; There is a drawback due to the thermal sensation of the animals and humidity, so it is necessary to supply fans (mechanical ventilation) for the chickens, in a quantity of three (3). Each fan has a flow of $16000 \mathrm{~m} 3 / \mathrm{h}$ and a power of $1.0 \mathrm{HP}$.

\section{REFERENCES}

[1] Bond, T., \& Kelly, C. (1960). Environment of animals. US Dept. Agr., US Government Printing Office, Washington, DC, 231-242. 
[2] González López, J. A. (2012). Cálculo y diseño de las instalaciones de una granja avícola.

[3] Cunningham, M. y Acker. (2000). Animal Science and Industry. Six Edition. Prentice Hall.

[4] King, G. (2000). Animals and environments. University of Guelph.

[5] Esmay, M. L. (1969). Principles of animal environment. Principles of animal environment.

[6] Wathes, C. M., \& Charles, D. R. (1994). Livestock housing. Wallingford (UK), CAB International, 1994.

[7] Miranda, F. F. (1997). Alojamientos para ganado porcino. Mira.

[8] Ambiente, M. (2012). Aplicación de los conceptos de ventilación. Selecciones avícolas.

[9] Vigoderis, R. B., Cordeiro, M. B., Tinôco, I. D. F. F., Menegali, I., Souza Júnior, J. P. D., \& Holanda, M. C. R. D. (2010). Avaliação do uso de ventilação mínima em galpões avícolas e de sua influência no desempenho de aves de corte no período de inverno. Revista Brasileira de Zootecnia, 39(6), 1381-1386.

[10] Robins, A., \& Phillips, C. J. C. (2011). International approaches to the welfare of meat chickens. World's Poultry Science Journal, 67(2), 351-369.

[11] Quiñonez Mera, B- (1985). Bioingeniería. Universidad Nacional - Sede Bogotá. Bogotá DC.

[12] IGAC-Instituto Geográfico Agustín Codazzi. 1969. Monografía del departamento de Sucre. Oficina de estudios geográficos. Bogotá DC.

[13] Hernández, C., \& Sánchez, E. (1992). Biomas terrestres de Colombia. Págs. 105-151 en: La diversidad biológica de Iberoamérica I. Halffter, G. CYTED. Inst. Mex. de Ecología y Secretaría de Desarrollo Social. México. 